\title{
Western flower thrips (Thysanoptera: Thripidae) preference for thrips-damaged leaves over fresh leaves enables uptake of symbiotic gut bacteria
}

\author{
Egbert J. DE VRIES ${ }^{1}$, Rutger A. VOS ${ }^{2}$, GerRit JACOBS ${ }^{1}$ and HANS A.J. BREEUWER ${ }^{1}$ \\ ${ }^{1}$ Institute for Biodiversity and Ecosystem Dynamics, University of Amsterdam, Kruislaan 320, 1098 SM Amsterdam, \\ The Netherlands; e-mail: vries@science.uva.nl \\ ${ }^{2}$ Simon Fraser University, Biology, TH60B 8888 University drive, Burnaby, British Columbia V5A 1S6, Canada
}

Key words. Oviposition preference, feeding preference, host plant selection, symbiosis, mutualism, Frankliniella occidentalis, Erwinia species

\begin{abstract}
To understand the evolution of insect gut symbionts it is important to determine how they are passed on to the next generation. We studied this process in Erwinia species bacteria that inhabit the gut of western flower thrips, Frankliniella occidentalis (Pergande) (Thysanoptera: Thripidae). This is a polyphagous herbivore and a world-wide pest in agricultural crops. With bacteria in the gut, the thrips larval development time can be shorter and its oviposition rate higher compared to bacteria-free thrips. Bacteria are not directly transmitted from mother to offspring, but larvae acquire bacteria from the leaves right after they hatch. These gut bacteria are present on the leaves on feeding sites used by other thrips before the larvae arrive, probably because these other thrips have deposited bacteria via faeces or regurgitation. In this study we addressed the question whether the transmission route of symbiotic bacteria influences the thrips feeding behaviour, and determined the feeding and oviposition preference of thrips, by giving them a choice between leaves with and leaves without prior grazing by other western flower thrips. This was studied for thrips with and thrips without gut bacteria. Young larvae prefer to feed on leaves that where grazed before by other thrips and females prefer to oviposit on these grazed leaves. These results are in contradiction to earlier studies that have found that thrips larvae fitness is lower on thrips damaged plants than on clean plants. This behaviour does however promote the establishment of gut bacteria in the thrips. The factors determining the preference for thrips-damaged leaves may be the physical leaf damage or odours that are produced by the plant, the bacteria or both.
\end{abstract}

\section{INTRODUCTION}

Gut bacteria in insects are usually commensals, but some of them are mutualists or parasites (Bignell, 1983; Campbell, 1990). Mutualistic gut bacteria may provide essential food components to the host, or enhance its internal defence against toxic compounds or parasites. Examples of the first are the gut symbionts of cockroaches and termites (Breznak, 1982; Cruden \& Markovetz, 1984), and of the second are symbionts that eliminate pathogenic fungi from the gut of the desert locust (Dillon et al., 2000). Earlier, we have described the bacterial species in the gut of western flower thrips (Frankliniella occidentalis), which is capable of enhancing the population growth rate of its host (De Vries et al., 2001a, b, 2004).

Hosts acquire symbiotic gut bacteria in various ways. In cockroaches, young larvae eat the eggshell or faeces that are infected with bacteria (Buchner, 1965; Koch, 1967). When the eggshell is infected with gut symbionts during oviposition, the bacteria are passed on directly from mother to offspring. In most cases, the bacteria are picked up when insects feed on plants or animals, contaminated with bacteria, such as the bacterial uptake by haematophagous insects (Hill et al., 1976; Demaio et al., 1996). Bacterial numbers in these bloodsucking insects increase right after a blood meal. For locusts and crickets, an equally strong coupling between feeding and increase in gut bacteria was observed (Kaufman et al., 1989; Dillon
\& Charnley, 1996). For symbiotic bacteria, uptake and transmission of bacteria are linked because both use the food source as a medium. After a visit of the insects, the plant leaf surface has bacterial species that are identical to the insect gut bacteria (Hunt \& Charnley, 1981; MacCollem et al., 1992; Thibout et al., 1995).

The question arises whether the uptake of bacteria from the surface of the food source is an accidental process, or whether the insect hosts are able to select the places to acquire the right bacteria. To determine if insects can actively select sites with potential symbiotic gut bacteria, we studied the preference of western flower thrips for plant leaves with and without gut bacteria. Western flower thrips, Frankliniella occidentalis (Pergande) (Thysanoptera: Thripidae), is an important pest insect in agricultural crops all over the world. They feed on leaves, flowers, and pollen, of many plant species in different taxa (Bryan \& Smith, 1956). Thrips harbour bacteria in the hindgut and Malpighian tubules (Ullman et al., 1989; De Vries et al., 1995), which belong to the Enterobacteriaceae on basis of $16 \mathrm{~S}$ rDNA sequence data (De Vries et al., 2001a). The insect gut is an open system suitable for different kinds of organisms, indeed in many cases a variety of bacterial species is found (Campbell, 1990). However, in the thrips gut one type of bacteria becomes dominant (De Vries et al., 2001a). This type of gut bacterium is an Erwinia species, and is further referred to as strain TAC (Thrips Amsterdam Chrysanthemum). Thrips with gut bacteria have a shorter larval development time 
and a higher egg production than thrips without gut bacteria (De Vries et al., 2004). This benefit to the thrips of the presence of gut bacteria is diet-dependent. On plant leaves, thrips benefit from the presence of bacteria in their gut system, but they do not on leaves with pollen.

Freshly hatched thrips are free of gut bacteria. The thrips acquire these bacteria during feeding on leaves (De Vries et al., 2001b). Thrips feeding causes small scars on leaves (Harrewijn et al., 1996). Probably, thrips also release gut bacteria on leaves, e.g., via the faeces. The small feeding scars will present a better habitat for heterotrophic bacteria than undamaged plants. These factors would explain the rapid uptake of similar gut bacteria by newly hatched larvae that are grazing from sites where other thrips have been feeding before (De Vries et al., 2001b). The prevalence of bacteria in thrips is the highest in second instar larvae (100\%; De Vries et al., 2001b). Possibly, larvae start eating at sites where other thrips are present. But what would happen if the thrips were offered a choice between a fresh leaf and a "used", but vacated, leaf? Would they select the leaf, earlier used by other thrips? In other words, do cues exist, other than the actual presence of conspecifics, which attract thrips to sites with potential gut bacteria? In this article we test the hypothesis that thrips prefer feeding from sites where other thrips have been eating, to fresh leaves. This hypothesis is tested by offering young larvae and young adult females the choice between a fresh leaf and a leaf that has been fed upon by other thrips before the test. We used two different populations of thrips in this study, one from cucumber plants and one from chrysanthemum plants. We made sure that the two populations were tested on different plants throughout the experiment, in order to be able to draw some conclusions on host plant effects in preference as well.

\section{MATERIAL AND METHODS}

\section{Thrips populations}

The thrips used in this study were obtained from two different thrips populations. One population was started in 1994 with a batch of thrips kindly provided by the Centre for Plant Breeding and Reproduction Research (CPRO-DLO) in the Netherlands, and maintained on chrysanthemum plants. The second population was started on cucumber plants in 1995 with thrips collected from greenhouses with the same crop in the Dutch Westland area. Thrips were reared on small $(\max .50 \mathrm{~cm})$ intact plants in a climate box $\left(25^{\circ} \mathrm{C}, 60 \%\right.$ r.h., and an $16 \mathrm{~L}: 8 \mathrm{D}$ photoperiod). These rearing conditions were used throughout this study for all experiments. The chrysanthemum plants (Dendranthema grandiflora) were obtained from local garden centres, whereas the cucumber plants (Cucumis sativa) were cultured in our own insect-free climate rooms. The populations were yearly checked for contamination with other thrips species (G. Vierbergen from the Netherlands Plant Protection Service, Wageningen). No contamination with other thrips species was detected.

\section{Host plants}

The experiments were done with cucumber leaves and bean leaves (Phaseolus vulgaris). These plants are known to support thrips growth very well, contrary to chrysanthemum leaves, on which thrips grow poorly (De Jager et al., 1995). The leaves were taken from plants that were grown in separate, insect-free compartments of the university greenhouse. In most experiments we used pollen as additional food. This pollen was obtained from Koppert Inc. (Naaldwijk, The Netherlands), and was a mixture of pollen from different plants species, collected by bees.

\section{Synchronised thrips rearing}

The choice experiments were done with batches of thrips from roughly the same age. These batches were made by taking adult females from the thrips culture and allowing them to oviposit for $24 \mathrm{~h}$ on leaves. After this, these leaves were placed in large Petri dishes $(200 \mathrm{~mm} \varnothing)$ on an agar layer. The dishes were made insect-proof by sealing them with parafilm. The larvae emerged after ca. three days and developed on the same leaf. Pollen was added as additional food. The new thrips were transferred to fresh leaves at the end of the second instar larval stage, where they pupated. After moulting, adult female thrips were used in our experiments. The batches from the chrysanthemum and the cucumber thrips population were both reared on bean plants to create similar conditions in the experiments.

\section{Rearing thrips from isolated eggs}

Rearing thrips from isolated eggs resulted in bacteria free thrips (De Vries et al., 2004). Normally, eggs of thrips are inserted inside the leaf tissue and they are hard to detect. As soon as the larvae hatch from the eggs, they crawl on the leaf surface and start feeding. Isolated eggs were collected when adult thrips oviposit in Murai cages (Murai \& Ishii, 1982), between the two sheets of parafilm, which contain a water layer. In these cages, the thrips feed on pollen. After removing the water, eggs were taken from the parafilm and incubated on wet filter paper for two more days. Thereafter the eggs were transferred to fresh leaves on an agar layer in a large petri dish (200 $\mathrm{mm} \varnothing$ ) and developed normally into larvae. These thrips were free of gut bacteria (aposymbionts).

\section{Checking the presence of gut bacteria}

The presence of gut bacteria in thrips was assessed after the experiment had taken place. The presence was determined by incubating thrips homogenate on Luria Bertoni agar plates. This medium is reliable in supporting growth of Erwinia species TAC bacteria (De Vries et al., 2001a). Thrips were individually homogenised after external sterilisation using a procedure described elsewhere (De Vries et al., 2001a). We incubated bacteria for $24 \mathrm{~h}$ at $25^{\circ} \mathrm{C}$, after which number and type of colonies were scored. Plates were considered positive if bacteria present were morphologically similar to thrips gut bacteria, type strain Erwinia species TAC. Following De Vries et al. (2001a) these are small, white, opaque, and round colonies with small motile rods. Plates containing less than 30 colonies were considered negative. Such a low number may have been caused by accidental contamination during the isolation procedure. The number of bacteria per thrips typically ranges from $10^{3}$ to $10^{5}$ (De Vries et al., 2001b).

\section{Feeding preference of larvae}

To determine whether thrips larvae prefer feeding sites where other thrips grazed before, a choice experiment was carried out. We used bacteria-free, isolated thrips eggs from the chrysanthemum thrips population. The eggs were placed individually on small pieces of wet filter paper (about three $\mathrm{mm}$ wide and ten $\mathrm{mm}$ long), on wet cotton in a large petri dish of $200 \mathrm{~mm} \varnothing$. On both sides of this filter paper, one half of a ten $\mathrm{mm} \varnothing$ leaf disc was placed. The two halves were placed against the long sides of the filter paper. The thrips larvae could therefore move quite easily from one half to the other half of the leaf disc. The two halves of the same leaf disc had a different pre-treatment. One 
half had not been attacked by any phytophagous arthropod prior to the experiment. On the other half, second instar thrips larvae had been feeding for $24 \mathrm{~h}$ before the experiment, and were removed thereafter. These thrips larvae were taken from the chrysanthemum thrips population and should all contain gut bacteria, because earlier studies have shown that the prevalence of thrips with bacteria is highest in the second instar larval phase (De Vries et al., 2001b).

In one petri dish, several (between 15 and 20) samples were put together. To avoid any bias to odours or light, the treated side of the leaf discs was alternately placed at the left or righthand side. The experiment was incubated under standard conditions $\left(25^{\circ} \mathrm{C}, 60 \%\right.$ r.h., $\left.16 \mathrm{~L}: 8 \mathrm{D}\right)$. After hatching of the thrips larvae, we scored the feeding preference of each larva by checking which half of the leaf disc it had selected to reside on. This was repeated every four h during a period of $12 \mathrm{~h}$, and after one day $(24 \mathrm{~h})$. In each replicate experiment, at least 25 thrips larvae were tested.

\section{Feeding preference of adult females}

The feeding preference of adult females was determined in a choice test. Females of approximately the same age were used. We offered each individual female a choice between two $10 \mathrm{~mm}$ $\varnothing$ leaf discs in a $90 \mathrm{~mm} \varnothing$ petri dish, on agar. The leaf discs were placed close together but did not touch each other. Again, leaf discs were placed on alternating positions. The female was placed in between the two leaf discs and the dish was incubated at standard conditions. The presence of the females on any of the two leaf discs was monitored during one day ( $12 \mathrm{~h})$, at intervals of two h. Thrips were subjected to several choice tests: between cucumber and bean leaf discs, between leaf discs with and without pollen, and between leaf discs which were grazed by other thrips prior to the experiment, and non-grazed leaf discs. These tests were done to determine whether a preference for grazed leaf discs over fresh leaf discs was influenced by other preferences. Each replicate contained at least 20 females and was repeated once. We tested females with and females without gut bacteria.

\section{Oviposition preference}

After testing the feeding preference of adult females, the same leaf discs were used to determine oviposition preference. The adult females were removed from the petri dish and the leaf discs were transferred to individual wells of a macrotitre plate, on agar. The wells were sealed with parafilm and the plates were incubated at standard conditions. After four days, all larvae present on each leaf disc were scored. All eggs should have hatched by that time (Van Rijn et al., 1995). Oviposition preference was expressed as the number of larvae produced by all females on one type of leaf disc, vs. the number of larvae produced by the same set of females on the other type of leaf disc. We tested females with and females without bacteria.

\section{Statistics}

Under the null hypothesis there is no preference, which implies a 50/50 ratio of feeding larvae or female adults, or a $50 / 50$ distribution of offspring, on the two types of leaf discs. A G-test was used to test for a significant deviation (Sokal \& Rohlf, 1995). Within one replicate, all data for each treatment were pooled. The combined result of various replicates of an experiment was determined using a replicated goodness-of-fit test. This G-statistical test allows for separate testing of homogeneity of the replicates and goodness of fit to the 50/50 distribution of all replicates together (Sokal \& Rohlf, 1995). We tested the results of the tests in our experiments; bean versus cucumber leaves, grazed versus non-grazed leaves, and leaves with pollen versus leaves without pollen. In several cases, it was found that the replicate results were heterogeneous, and overall significantly deviating from a 50/50 distribution. In these cases, separate results of G-tests on 50/50 distribution in the individual replicates were presented. It turned out that with this number of replicates in each test, the results could be heterogeneous even when all results showed the same trend, but not all of the individual results were significantly deviating from the 50/50 distribution.

\section{RESULTS}

\section{Feeding preference of young thrips larvae}

The experiment with clean bean leaves and grazed bean leaves showed a feeding preference of young thrips larvae for grazed leaf discs. In both replicates, significantly more thrips larvae were found on the leaf half that was grazed by other thrips before the experiment started (grazed leaf disc) (Table 1). These leaf discs contain Erwinia TAC bacteria. Preference for non-grazed leaf discs was not observed at any of the eight measure points. The number of larvae taking part in the experiments increased over time because $\mathrm{t}=0$ was set at the time when the first larvae hatched from the egg, and there is quite a spread in hatching time.

\section{Feeding preference of adult females and oviposition preference}

The feeding preference of adult females was difficult to determine. Most of the time, females were not present on any of the two leaf discs but on the petri dish or on the agar. The number of scores for any of the two leaf discs was not high enough to draw reliable conclusions about food preference. We therefore decided to concentrate on oviposition preference of the females. We determined various aspects of oviposition preference: host plant preference (bean or cucumber); influence of the presence of pollen as additional food source; and the preference for grazed or non-grazed leaf discs. Thrips of both popula-

TABLE 1. Preference of young western flower thrips larvae for grazed leaf discs over clean leaf discs. The grazed leaf discs had been used as food source by other thrips larvae during $24 \mathrm{~h}$ prior to the start of the experiment. Leaf discs were halves of the same original leaf disc. The percentage of thrips choosing for grazed leaves is presented. The other thrips were on clean leaf discs. The experiment was done with eggs that had roughly the same age. The time of experiment was set at zero at moment when the first ten eggs had hatched. Significant deviations from the expected 50/50 distribution are mentioned in the table $\left(\chi^{2}\right) . n$ $=$ number of larvae scored.

\begin{tabular}{ccccc}
\hline Replicate & $\begin{array}{c}\text { Time of } \\
\text { experiment (h) }\end{array}$ & $\begin{array}{c}\text { Percentage of larvae } \\
\text { on grazed leaf disc }\end{array}$ & $\chi^{2}$ & $\mathrm{n}$ \\
\hline I & 4 & 58 & $\mathrm{~ns}$ & 25 \\
& 8 & 64 & $\mathrm{~ns}$ & 33 \\
& 12 & 76 & $*$ & 44 \\
& 24 & 82 & $* *$ & 38 \\
\hline II & 4 & 91 & $* *$ & 11 \\
& 8 & 88 & $* *$ & 15 \\
& 12 & 83 & $* *$ & 18 \\
& 24 & 82 & $* *$ & 22 \\
\hline
\end{tabular}

$\mathrm{ns}=$ non-significant; $*=\mathrm{p}>0.05 ; * *=\mathrm{p}>0.01$. 
TABLE 2A. Preference of western flower thrips to oviposition on cucumber over bean leaf discs in a choice test. Two thrips populations (with either chrysanthemum or cucumber as original host plant) were tested. The oviposition preference is expressed as the sum of the number of eggs produced by 20 individually tested females. Thrips laid eggs for $24 \mathrm{~h}$.

\begin{tabular}{lccc}
\hline \multirow{2}{*}{ Thrips } & \multirow{2}{*}{ Replicate } & \multicolumn{2}{c}{ Leaf disc } \\
\cline { 3 - 4 } & & Bean & Cucumber \\
\hline Chrysanthemum & I & 11 & 36 \\
population & II & 7 & 13 \\
\hline Cucumber & I & 8 & 41 \\
population & II & 3 & 40 \\
\hline
\end{tabular}

tions have a clear oviposition preference for leaves fed upon by other thrips prior to the experiment, which were the leaves with bacteria (Table 4A). Apparently, this preference overrules other preferences such as the preference for cucumber leaves over bean leaves (Tables $2 \mathrm{~A}$ and 4A).

First of all, thrips prefer to lay eggs in cucumber leaves rather than in bean leaves (Table 2A). This preference is independent of the original host plant of the thrips population under study, because in both populations, the deviation from the $1: 1$ distribution on cucumber and bean leaves was significant at 0.01 level (Table 2B). Secondly, it appeared that most thrips prefer leaf discs with pollen to leaf discs without pollen (Table 3A). For both thrips populations studied, this preference was significant at 0.01 level (Table 3B). Both thrips populations showed a significant heterogeneity among the replicates when the situation with pollen was compared to no pollen. However, the trend was clear and similar for each replicate. Only one replicate of each population did not show a significant deviation from the expected $1: 1$ distribution, but a trend towards pollen. This replicate probably caused the overall heterogeneity of the results.

This preference for pollen was overruling the aforementioned preference of cucumber over bean, as was confirmed by the overall relative goodness of fit to the $1: 1$ distribution in the thrips from both populations in this pollen experiment (Table 3B). In all these tests thrips contained gut symbionts, as was confirmed by isolating large amounts of bacteria from individual females after the test (data not shown).

Finally, it was measured whether adult female thrips prefer to oviposit in the leaf discs that have been used as food source by other thrips prior to the experiment
TABLE 2B. Statistical analysis of Table $2 \mathrm{~A}$ with a relative goodness-of-fit test on all data, and on data per population separately. We tested the heterogeneity among replicates $\left(\mathrm{G}_{\mathrm{H}}\right)$, the overall goodness of fit to a $50 / 50$ distribution $\left(\mathrm{G}_{\mathrm{P}}\right)$, and the total heterogeneity $\left(G_{T}=G_{H}+G_{P}\right)$. d.f. = degrees of freedom.

\begin{tabular}{lrcc}
\hline Test & G value & d.f. & $\chi^{2}$ \\
\hline Overall replicate heterogeneity $(\mathrm{GH})$ & 7.82 & 3 & $\mathrm{~ns}$ \\
Overall goodness-of-fit to 50:50 $(\mathrm{Gp})$ & 69.36 & 1 & $* * *$ \\
Overall total heterogeneity $(\mathrm{GT})$ & 78.04 & 4 & $* *$ \\
Cucumber population GH & 2.00 & 1 & $\mathrm{~ns}$ \\
Cucumber population GP & 60.18 & 1 & $* * *$ \\
Cucumber population GT & 62.18 & 2 & $* * *$ \\
Chrysanthemum population GH & 2.12 & 1 & $\mathrm{~ns}$ \\
Chrysanthemum population GP & 14.91 & 1 & $* * *$ \\
Chrysanthemum population GT & 17.03 & 2 & $* * *$ \\
\hline
\end{tabular}

$\mathrm{ns}=$ non-significant; $* *=\mathrm{p}<0.01 ; * * *=\mathrm{p}<0.001$.

("grazed" leaves), instead of clean, insect-free leaf discs ("non-grazed" leaves). It appeared that in 21 out of 32 replicates there was a significant preference for the grazed leaf discs over the non-grazed leaves (Table 4A). The other replicates showed no significant deviation from the $1: 1$ distribution (but a trend towards the grazed leaf disc - except for one replicate), or a significant preference for the clean leaf disc ( 3 out of 32 replicates). The data did not show homogeneity when all replicates of a similar experiment were combined (Table 4B). However, we decided to use the combined results because of the clear visible trend in the data.

The preference for grazed leaf discs over clean leaf discs was significant at the 0.01 level in the test for the overall relative goodness of fit to a $1: 1$ distribution, and this effect was present in both populations of thrips studied (Table 4B). It was found that the preference for grazed leaf discs partly overruled the preference for cucumber leaf discs over bean leaf discs shown earlier (Table 2A). In the thrips of the cucumber population (all thrips and symbionts only) and the thrips of the chrysanthemum population (aposymbionts) no significant deviation from the $1: 1$ distribution over cucumber and bean leaves was found (Table 4B). In 13 out of the 16 replicates where bean leaves were grazed and cucumber leaves were not grazed, the bean leaves were preferred. The overall heterogeneity between replicates was therefore higher when bean leaves were tested against cucumber leaves, than in the situation of grazed leaves vs. non-grazed leaves.

Table 3A. Preference of western flower thrips females to oviposit on leaf discs with pollen rather than on leaf discs with no pollen. The pollen used in this experiment is bee-collected and derived from various host plants. The preference is expressed as the total number of eggs produced by 20 individually tested females. For each replicate, significant deviations from the expected $50 / 50$ distribution are mentioned in the table $\left(\chi^{2}\right)$. The females were laying eggs for $24 \mathrm{~h}$. Repl = replicate.

\begin{tabular}{lccccccc}
\hline \multirow{2}{*}{ Thrips } & \multirow{2}{*}{ Repl } & \multicolumn{7}{c}{ Leaf disc } \\
\cline { 3 - 8 } & & Bean + pollen & Cucumber no pollen & $\chi^{2}$ & Bean no pollen & Cucumber + pollen & $\chi^{2}$ \\
\hline \multirow{2}{*}{ Chrysanthemum population } & I & 37 & 12 & $* *$ & 9 & 43 & $* * *$ \\
& II & 32 & 21 & ns & 14 & 25 & 59 \\
\hline \multirow{2}{*}{ Cucumber population } & I & 39 & 12 & $* *$ & 25 & 34 & ns \\
& II & 64 & 23 & $* *$ & 19 & 61 & $* *$ \\
\hline
\end{tabular}

ns $=$ non-significant $* *=\mathrm{p}<0.01 ; * * *=\mathrm{p}<0.001$. 
TABLE 3B. Statistical analysis of Table 3A with a relative goodness-of-fit test on all data, and on data per population separately. We tested the heterogeneity among replicates $\left(\mathrm{G}_{\mathrm{H}}\right)$, the overall goodness of fit to a 50/50 distribution $\left(\mathrm{G}_{\mathrm{P}}\right)$, and the total heterogeneity $\left(G_{T}=G_{H}+G_{P}\right)$. Both the plant food source and the presence of pollen are tested. d.f. = degrees of freedom.

\begin{tabular}{|c|c|c|c|c|c|c|c|c|c|}
\hline \multirow{2}{*}{ Test } & \multicolumn{3}{|c|}{ Replicate heterogeneity } & \multicolumn{3}{|c|}{ Goodness-of-fit } & \multicolumn{3}{|c|}{ Total heterogeneity } \\
\hline & $\mathrm{G}_{\mathrm{H}}$ & d.f. & $\chi^{2}$ & $\mathrm{G}_{\mathrm{P}}$ & d.f. & $\chi^{2}$ & $\mathrm{G}_{\mathrm{T}}$ & d.f. & $\chi^{2}$ \\
\hline \multicolumn{10}{|l|}{ Pollen : no pollen } \\
\hline Overall & 22.4 & 7 & $* *$ & 126.0 & 1 & $* * *$ & 148.4 & 8 & $* * *$ \\
\hline Cucumber population & 19.8 & 3 & $* * *$ & 52.82 & 1 & $* * *$ & 72.62 & 4 & $* * *$ \\
\hline Chrysanthemum pop & 8.6 & 3 & $*$ & 61.1 & 1 & $* * *$ & 69.7 & 4 & $* * *$ \\
\hline \multicolumn{10}{|l|}{ Cucumber : bean } \\
\hline Overall & 51.5 & 7 & $* * *$ & 0.5 & 1 & NS & 52.1 & 8 & $* * *$ \\
\hline Cucumber population & 71.6 & 3 & $* * *$ & 1.1 & 1 & NS & 72.7 & 4 & $* * *$ \\
\hline Chrysanthemum pop & 61.5 & 3 & $* * *$ & 8.2 & 1 & $* *$ & 69.7 & 4 & $* * *$ \\
\hline
\end{tabular}

ns $=$ non-significant; $*=\mathrm{p}<0.05 ; * *=\mathrm{p}<0.01 ; * * *=\mathrm{p}<0.001$.

In this last set of experiments we used aposymbiotic and symbiotic females. The presence of bacteria was checked for each group, and indeed only the symbiotic females contained bacteria (data not shown). There was little difference in oviposition preference between bacteria-free and infected thrips (Table 4A). In two replicates, the symbiotic thrips of the chrysanthemum population preferred non-grazed cucumber leaves over grazed bean leaves, whereas in none of the replicates of aposymbiotic chrysanthemum thrips this was case. However in the cucumber population this was not found at all. The comparison of data between aposymbiotic and symbiotic thrips showed that both had significant preference for the grazed leaves (significant at 0.01 level, Table 4B). The results did not differ from the overall results when aposymbiotic and symbiotic thrips were combined.

\section{Variation between thrips populations}

Overall, there was no difference in female oviposition choice between the thrips populations from cucumber or chrysanthemum. For both populations we found that cucumber leaves are preferred over bean leaves, leaves with pollen over leaves without, and leaves grazed by other thrips prior to the experiment over clean leaves (Tables 2, 3, and 4).

\section{DISCUSSION}

Thrips acquire directly after hatching gut bacteria, which grow in number during the larval feeding stages (De Vries et al., 2001b). Thrips with gut bacteria have a

TABLE 4A. Preference of western flower thrips females to oviposit on leaf discs with potential gut bacteria rather than on leaf discs without. Both thrips with (Sym) and without (Apo) gut bacteria were tested, from two populations. One population originated from cucumber, the other population from chrysanthemum. The cucumber and bean leaf discs in this experiment obtained bacteria by exposing them to grazing by a random sample of second instar thrips larvae in the $24 \mathrm{~h}$ prior to the test ("grazed"). Oviposition preference is expressed as the sum of the number of eggs produced by 20 individually tested females. Thrips were laying eggs for $24 \mathrm{~h}$. For each replicate, significant deviations from the expected 50/50 distribution are mentioned in the table $\left(\chi^{2}\right)$. Bact $=$ thrips with or without gut bacteria. Repl $=$ replicate.

\begin{tabular}{|c|c|c|c|c|c|c|c|c|}
\hline \multirow{2}{*}{ Thrips } & \multirow{2}{*}{ Bact } & \multirow{2}{*}{ Repl } & \multicolumn{6}{|c|}{ Leaf disc } \\
\hline & & & Bean grazed & Cucumber clean & $\chi^{2}$ & Bean clean & Cucumber grazed & $\chi^{2}$ \\
\hline \multirow{8}{*}{ Chrysanthemum population } & \multirow[t]{4}{*}{ Apo } & I & 12 & 8 & ns & 9 & 30 & $* *$ \\
\hline & & II & 24 & 11 & ns & 25 & 48 & $* *$ \\
\hline & & III & 19 & 3 & $* *$ & 12 & 31 & $* *$ \\
\hline & & IV & 26 & 19 & $\mathrm{~ns}$ & 9 & 41 & $* *$ \\
\hline & \multirow[t]{4}{*}{ Sym } & I & 8 & 21 & $* *$ & 7 & 43 & $* * *$ \\
\hline & & II & 10 & 34 & $* *$ & 12 & 31 & $* *$ \\
\hline & & III & 21 & 12 & ns & 3 & 23 & $* * *$ \\
\hline & & IV & 34 & 19 & $*$ & 6 & 37 & $* *$ \\
\hline \multirow{8}{*}{ Cucumber population } & \multirow[t]{4}{*}{ Apo } & $\mathrm{I}$ & 24 & 19 & $\mathrm{~ns}$ & 14 & 38 & $* *$ \\
\hline & & II & 5 & 26 & $* *$ & 5 & 17 & $*$ \\
\hline & & III & 35 & 24 & ns & 4 & 18 & $* *$ \\
\hline & & IV & 31 & 16 & $*$ & 8 & 27 & $* *$ \\
\hline & \multirow[t]{4}{*}{ Sym } & $\mathrm{I}$ & 25 & 12 & $*$ & 10 & 37 & $* *$ \\
\hline & & II & 22 & 17 & ns & 7 & 29 & $* *$ \\
\hline & & III & 27 & 13 & $*$ & 10 & 29 & $* *$ \\
\hline & & IV & 21 & 8 & $*$ & 31 & 18 & $\mathrm{~ns}$ \\
\hline
\end{tabular}

ns $=$ non-significant; $*=\mathrm{p}<0.05 ; * *=\mathrm{p}<0.01 ; * * *=\mathrm{p}<0.001$. 
TABLE 4B. Statistical analysis of Table 4A with a relative goodness-of-fit test on all data, and on data per population separately. We tested the heterogeneity among replicates $\left(\mathrm{G}_{\mathrm{H}}\right)$, the overall goodness of fit to a 50/50 distribution $\left(\mathrm{G}_{\mathrm{P}}\right)$, and the total heterogeneity $\left(\mathrm{G}_{\mathrm{T}}=\mathrm{G}_{\mathrm{H}}+\mathrm{G}_{\mathrm{P}}\right)$. Both the plant food source and the presence of pollen are tested. The aposymbiont thrips and symbiont thrips are treated separately, and combined. d.f $=$ degrees of freedom.

\begin{tabular}{|c|c|c|c|c|c|c|c|c|c|}
\hline \multirow{2}{*}{ Test } & \multicolumn{3}{|c|}{ Replicate heterogeneity } & \multicolumn{3}{|c|}{ Goodness-of-fit } & \multicolumn{3}{|c|}{ Total heterogeneity } \\
\hline & $\mathrm{G}_{\mathrm{H}}$ & d.f. & $\chi^{2}$ & $\mathrm{G}_{\mathrm{P}}$ & d.f. & $\chi^{2}$ & $\mathrm{G}_{\mathrm{T}}$ & d.f. & $\chi^{2}$ \\
\hline \multicolumn{10}{|l|}{ SymBionts } \\
\hline \multicolumn{10}{|l|}{ Grazed : non-grazed } \\
\hline Overall & 107.8 & 15 & $* * *$ & 59.4 & 1 & $* * *$ & 167.2 & 16 & $* * *$ \\
\hline Cucumber population & 28.8 & 7 & $* * *$ & 32.2 & 1 & $* * *$ & 61.0 & 8 & $* * *$ \\
\hline Chrysanthemum pop & 80.9 & 7 & $* * *$ & 27.3 & 1 & $* * *$ & 108.2 & 8 & $* * *$ \\
\hline \multicolumn{10}{|l|}{ Cucumber : bean } \\
\hline Overall & 140.9 & 15 & $* * *$ & 26.3 & 1 & $* * *$ & 167.2 & 16 & $* * *$ \\
\hline Cucumber population & 60.7 & 7 & $* * *$ & 0.3 & 1 & $\mathrm{~ns}$ & 61.0 & 8 & $* * *$ \\
\hline Chrysanthemum pop & 100.9 & 7 & $* * *$ & 7.2 & 1 & $* *$ & 108.1 & 8 & $* * *$ \\
\hline
\end{tabular}

\section{Aposymbionts}

Grazed : non-grazed

\begin{tabular}{lcccccccccc} 
Overall & 56.9 & 15 & $* * *$ & 79.2 & 1 & $* * *$ & 136.1 & 16 & $* * *$ & \\
Cucumber population & 41.8 & 7 & $* * *$ & 20.3 & 1 & $* * *$ & 62.1 & 8 & $* * *$ & \\
Chrysanthemum pop & 103.3 & 7 & $* * *$ & 57.4 & 1 & $* * *$ & 160.7 & 8 & $* * *$ & \\
ucumber : bean & & & & & & & & & & \\
Overall & 4.2 & 15 & $\mathrm{~ns}$ & 20.5 & 1 & $* * *$ & 24.7 & 16 & $\mathrm{~ns}$ \\
Cucumber population & 50.8 & 7 & $* * *$ & 12.0 & 1 & $* * *$ & 62.8 & 8 & $* * *$ \\
Chrysanthemum pop & 55.1 & 7 & $* * *$ & 3.3 & 1 & $\mathrm{~ns}$ & 58.4 & 8 & $* * *$ \\
\hline
\end{tabular}

AlL

Grazed : non-grazed

Overall

Cucumber population

$51.28 \quad 31$

Chrysanthemum pop

$71.28 \quad 15$

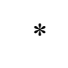

$* * *$

Cucumber : bean

Overall

Cucumber population

Chrysanthemum pop

$\begin{array}{lll}7.42 \quad \text { ns } & 15\end{array}$

79.97

46.61

0.2

47.78

\begin{tabular}{c}
132.23 \\
51.28 \\
79.97 \\
\\
46.61 \\
0.2 \\
47.78 \\
\hline
\end{tabular}

$\begin{array}{ll}1 & * * * \\ 1 & * * * \\ 1 & * * * \\ 1 & \\ 1 & \\ 1 & * * *\end{array}$

$\begin{array}{cccc}* * * & 183.51 & 32 & * * * \\ * * * & 122.56 & 16 & * * * \\ * * * & 89.39 & 16 & * * * \\ & & & \\ * * * & 173.53 & 32 & * * * \\ \mathrm{~ns} & 121.8 & 16 & * * * \\ * * * & 60.98 & 16 & * * *\end{array}$

ns $=$ non-significant; $*=\mathrm{p}<0.05 ; * *=\mathrm{p}<0.01 ; * * *=\mathrm{p}<0.001$.

shorter larval period and a higher egg production on bean leaves than bacteria-free thrips (De Vries et al., 2004). Adult thrips are not confined to leaves, but have the opportunity to move to flowers and can also feed on nectar or pollen. Larvae that hatched on leaves cannot move easily to other food sources and would probably benefit directly from the presence of the type of gut bacteria normally present in thrips. So, it is more important for larvae to possess gut symbionts than for adults, which is consistent with the high number of bacteria per thrips in second instar larvae. Interestingly, as we described earlier (De Vries et al., 2001b), transmission of bacteria to newly born thrips is horizontal. The route of transmission involves picking up bacteria from the plant surface, where they probably were deposited by other thrips during feeding.

Thus, if there is no pollen present, it would be advantageous for newly hatched thrips larvae to find sites where potential gut symbionts are located. Indeed, our results indicate that young thrips larvae are able to select the par- ticular feeding sites that other thrips had visited before (Table 1). This is not the first study to report insect feeding behaviour that enhances uptake of internal bacteria. A similar capacity to select sites with bacteria was described before in the fruit flies, which have other Enterobacteriaceae gut bacteria (MacCollem et al., 1992; Martinez et al., 1994). Several other mechanisms to enhance uptake of gut bacteria have been described. In cockroaches the necessary gut methanogens are passed on via faeces. They produce a volatile compound that probably acts as an aggregation pheromone to attract the insect host (Cruden \& Markovetz, 1984). Additionally, bacteria from bark beetles that are deposited in faeces are able to produce verbenol, the bark beetle aggregation pheromone (Brand et al., 1975). In locusts, the beneficial gut bacteria also have to be obtained via the food source and these bacteria also produce aggregation pheromones in the faeces (Dillon et al., 2002). So both hosts and bacteria use different ways to promote symbiont uptake. 
Aggregation behaviour has been described for thrips as well (Kirk, 1985; Terry \& Dyreson, 1996). It is however primarily found with adult males and therefore it probably plays a role in mating and lekking behaviour rather than in feeding or oviposition (Terry, 1997, and references therein). We specifically decided not to study the preference of thrips for feeding sites with or without other thrips, but rather studied individual thrips, to exclude possible confounding effects of aggregation behaviour. Matteson \& Terry (1992) described how flower colour may affect aggregation in thrips. We have found no references regarding the role that odours and/or gut bacteria may play in thrips aggregation. The interesting question in this respect, whether thrips faeces (with or without interference of the gut bacteria) contain aggregation pheromones has not been answered yet.

The thrips preference to feeding and ovipositing on sites where other thrips have been feeding seems to be rather exceptional. Usually, it is found that phytophagous conspecifics avoid each other, and also avoid other competitors, see for example the spider mite Tetranychus urticae (Pallini et al., 1997; Janssen et al., 1998). Interestingly, Pallini (1999) found that thrips do not avoid nor prefer feeding sites invaded by spider mites. It is not known whether spider mites have gut bacteria and if so, whether these are the same to the bacteria of thrips. Preliminary investigations on the presence of this type of bacteria in spider mites showed no results (De Vries, data not shown).

In their study on thrips fitness on plants with and without infection of plant virus (TSWV), Belliure et al. (2005) found that thrips larvae have a better fitness on clean plants than on thrips damaged plants. They compared clean plants with plants of similar age that had been used by thrips in the two weeks prior to the experiment. In other words, it should not be in the interest of thrips to have the preference for damaged plants that we have found in this study. The damaged plants must offer other advantages to the thrips than direct fitness advantages. Other studies show that among the cues used by thrips to select feeding or oviposition sites are colour and odours. Thrips respond to several different odours that can be produced by plants (Terry, 1997, and references therein). The olfactory sensors were described in previous studies (Hunter \& Ullman, 1992). Generally, it was found that thrips adults prefer flowers to leaves (Yudin et al., 1988; De Jager et al., 1993; Kirk, 1997, and references therein), which is confirmed by our data on female oviposition preference for leaves with pollen (Table 3). Plants infected with virus (TSWV) offer a more suitable environment for thrips larvae, even when these plants are damaged by thrips feeding (Maris et al., 2004, Belliure et al., 2005). Other studies have shown that these pathogens may be able to actively attract insect vectors to the host plants (Eigenbrode et al., 2002).

The mechanism that causes the thrips preference for feeding sites occupied by other thrips is not clear. It could be the physical effect of grazing, or certain odours released as a result of grazing or deposition of bacteria (or both!). Thrips grazing causes crater-like scars on the leaves, which may offer a better feeding site to any herbivore because it allows easier access to the plant tissue (Harrewijn et al., 1996). Indeed, De Jager et al. (1995) found a positive correlation between the number of thrips eggs produced and the leaf feeding damage in chrysanthemum. If attractants or arrestment cues play a role in thrips feeding site selection, we cannot differentiate between compounds originating from bacterial activity, or compounds originating from thrips-damaged host plants. Odours emitted during or after feeding may be produced by the feeding thrips or by the plant itself, after induction by the thrips. In fact the question what came first, attraction to bacteria or attraction to feeding sites, is a chickenand-egg problem that cannot be answered with this experiment. However, it is hard to circumvent this problem, and design experiments that do answer this question straightforwardly. Simply using aposymbiotic and symbiotic thrips is not enough because eliminating bacteria from the thrips does also influence the thrips itself, as was shown in our previous studies (De Vries et al., 2004). Besides, aposymbiotic and symbiotic thrips do not seem to be behaving differently according to our experiments. Further studies could also include tests on whether thrips preference for grazed/damaged leaves is changed in the presence of pollen.

ACKNOWLEDGEMENTS. Insect-free cucumber plants were provided by A. Janssen and A. Pallini from the Institute for Biodiversity and Ecosystem Dynamics of the University of Amsterdam. T. Overzier is acknowledged for supplying us with bean plants. We thank B. Vierbergen from the Plant Protection Service, Wageningen, for morphological identification of the thrips populations used in this study. M. Sabelis, A. Janssen, and S. Menken gave valuable comments on earlier versions of this manuscript. The paper was improved thanks to the comments of two anonymous reviewers. G. Jacobs and E. de Vries were supported by grant 22.2704 from the Technology Foundation of the Netherlands Organisation for Scientific Research. H. Breeuwer was supported by the Royal Netherlands Academy for Arts and Sciences.

\section{REFERENCES}

Belliure B., Janssen A., Maris P.C., Peters D. \& Sabelis M.W. 2005: Herbivore arthropods benefit from vectoring plant viruses. Ecol. Lett. 8: 70-79.

Bignell D.E. 1983: The arthropod gut as an environment for micro-organisms. In Clarke R.T.J. \& Bauchop T. (eds): Microbial Ecology of the Gut. Academic Press, New York, NY, pp. 205-227.

Brand J.M., Bracke J.W., Markovetz A.J., Wood D.L. \& BRowne L.E. 1975: Production of verbenol pheromone by a bacterium isolated from bark beetles. Nature 254: 136-137.

BREZNAK J.A. 1982: Intestinal microbiota of termites and other xylophagous insects. Annu. Rev. Microbiol. 36: 323-343.

BRYAN D.E. \& SмITH R.F. 1956: The Frankliniella occidentalis (Pergande) complex in California (Thysanoptera: Thripidae). Univ. Calif. Publ. Entomol. 10: 359-410.

Buchner P. 1965: Endosymbiosis of Animals with Plant Microorganims. John Wiley, New York, NY, 905 pp.

CAmpBell B.C. 1990: On the role of microbial symbiotes in herbivorous insects. In Bernays E.A. (ed.): Insect-Plant Interaction. CRC Press, Boca Raton, FA, pp. 1-45. 
Cruden D.L. \& Markovetz A.J. 1984: Microbial aspects of the cockroach hindgut. Arch. Microbiol. 138: 131-139.

De Jager C.M., Butot R.P.T., De Jong T.J., Klinkhamer P.G.L. \& VAN DER MeIJden E. 1993: Population growth and survival of western flower thrips Frankliniella occidentalis Pergande (Thysanoptera: Thripidae) on different chrysanthemum cultivars: two methods for measuring resistance. J. Appl. Entomol. 115: 519-525.

De Jager C.M., Butot R.P.T., Klinkhamer P.G.L., De Jong T.J., Wolff K. \& Van der MeIJden E. 1995: Genetic variation in chrysanthemum for resistance to Frankliniella occidentalis (Thysanoptera: Thripidae). Entomol. Exp. Appl. 77: 277-287.

Demaio J., Pumpuni C.B., Kent M. \& Beier J.C. 1996: The midgut bacterial flora of wild Aedes triseriatus, Culex pipiens, and Psorophora columbiae mosquitoes. Am. J. Trop. Med. Hyg. 54: 219-223.

De Vries E.J., Jacobs G. \& Breeuwer J.A.J. 1995: Symbiotic bacteria of the Western Flower Thrips, Frankliniella occidentalis. Proc. Exp. Appl. Entomol. NEV 6: 87-92.

De Vries E.J., Breeuwer J.A.J., Jacobs G. \& Mollema C. 2001a: The association of western flower thrips, Frankliniella occidentalis, with a near Erwinia species gut bacteria: transient or permanent? J. Invert. Pathol. 77: 120-128.

De Vries E.J., Jacobs G. \& Breeuwer J.A.J. 2001b: Growth and transmission of gut bacteria in the western flower thrips, Frankliniella occidentalis. J. Invert. Pathol. 77: 129-137.

De Vries E.J., Jacobs G., Breeuwer J.A.J., Sabelis M.W. \& MenKen S.B.J. 2004: Diet dependent fitness effects of gut bacteria on their insect host: the symbiosis of Erwinia sp. and western flower thrips. Proc. R. Soc. Lond. (B) 271: 2171-2178

Dillon R.J. \& Charnley A.K. 1996: Colonization of the guts of germ-free desert locusts, Schistocerca gregaria, by the bacterium Pantoea agglomerans. J. Invert. Pathol. 67: 11-14.

Dillon R.J., Vennard C.T. \&. Charnley A.K. 2000: Exploitation of gut bacteria in the locust. Nature 403: 851 .

Dillon R.J., Vennard C.T. \&. Charnley A.K. 2002: A note: gut bacteria produce components of locust cohesion pheromone. J. Appl. Microbiol. 92: 759-763.

Eigenbrode S.D., Ding H.J., Shiel P. \& Berger P.H. 2002: Volatiles from potato plants infected with potato leafroll virus attract and arrest the virus vector, Myzus persicae (Homoptera: Aphididae). Proc. R. Soc. Lond. (B) 269: 455-460.

Harrewijn P., Tuallingil F. \& Mollema C. 1996: Electrical recording of plant penetration by western flower thrips. Entomol. Exp. Appl. 79: 345-353.

Hill P., Campbell J.A. \& Petrie I.A. 1976: Rhodnius prolixus and its symbiotic actinomycete: a microbiological, physiological and behavioural study. Proc. R. Soc. Lond. (B) 194: 501-524.

Hunt J. \& ChARnLEy A.K. 1981: Abundance and distribution of the gut flora of the desert locust, Schistocerca gregaria. $J$. Invert. Pathol. 38: 378-385.

Hunter W.B. \& UlLman D.E. 1992: Anatomy and ultrastructure of the piercing sucking mouthparts and paraglossal sensilla of Frankliniella occidentalis (Pergande) (Thysanoptera: Thripidae). Int. J. Insect Morphol. Embryol. 18: 161-171.

Janssen A., Pallini A., Venzon M. \& SABelis M.W. 1998: Behaviour and indirect interactions in food webs of plantinhabiting arthropods. Exp. Appl. Acarol. 22: 497-521.
Kaufman M.G., Klug M.J. \& MerRit R.W. 1989: Growth and food utilization parameters of germ-free house crickets, Acheta domesticus. J. Insect Physiol. 35: 957-967.

KIRK W.D.J. 1985: Aggregation and mating of thrips in flowers of Calystega sepium. Ecol. Entomol. 10: 433-440.

KIRK W.D.J. 1997: Feeding. In Lewis T. (ed.): Thrips as Crop Pest. CAB International, New York, NY, pp. 119-174.

KocH A. 1967: Insects and their endosymbionts. In Henry S.M. (ed.): Symbiosis. Vol. 2. Associations of Invertebrates, Birds, Ruminants and Other Biota. Academic Press, New York, NY, pp. 1-106.

MacCollem G.B., Lauzon C.R., Weires Jr. R.W. \& RutKowski A.A. 1992: Attraction of the adult apple maggot (Diptera: Tephritidae) to microbial isolates. J. Econ. Entomol. 85: 83-87.

Maris P.C., Joosten N.N., Goldbach R.W. \& Peters D. 2004: Tomato spotted wilt virus infection improves host suitability for its vector Frankliniella occidentalis. Phytopathology 94: 706-711.

Martinez A.J., Robacker D.C., Garcia J.A. \& Esau K.L. 1994: Laboratory and field olfactory attraction of the Mexican fruit fly (Diptera: Tephritidae) to metabolites of bacterial species. Fla Entomol. 77: 117-126.

Matteson N. \& Terry L.I. 1992: Response to color by male and female Frankliniella occidentalis during swarming and nonswarming behavior. Entomol. Exp. Appl. 63: 187-201.

MuraI T. \& IsHII T. 1982: Simple rearing methods for flower thrips (Thysanoptera: Thripidae) on pollen. Jap. J. Appl. Entomol. Zool. 26: 149-154 [in Japanese].

Pallini A. 1999: Odour-Mediated Indirect Interactions in an Arthropod Food Web. PhD thesis, University of Amsterdam, Amsterdam, $91 \mathrm{pp}$.

Pallini A., Janssen A. \& Sabelis M.W. 1997: Odour-mediated responses of phytophagous mites to conspecific and heterospecific competitors. Oecologia 110: 179-185.

SoKal R.R. \& RohlF F.J. 1995: Biometry. 3rd ed. W.H. Freeman, New York, NY, 850 pp.

TERRY L.I .1997: Host selection, communication, and reproductive behaviour. In Lewis T. (ed.): Thrips as Crop Pest. CAB International, New York, NY, pp. 65-118.

Terry L.I. \& Dyreson E. 1996: Behavior of Frankliniella occidentalis (Thysanoptera: Thripidae) within aggregations, and morphometric correlates of fighting. Ann. Entomol. Soc. Am. 89: 589-602.

Thibout E., Guillot J.F., Ferary S., Limouzin P. \& Auger J. 1995: Origin and identification of bacteria which produce kairomones in the frass of Acrolepiopsis assectella (Lep., Hyponomeutidae). Experientia 51: 1073-1075.

Ullman D.E., Westcott D.M., Hunter W.B. \&. Mau R.F.L. 1989: Internal anatomy and morphology of Frankliniella occidentalis (Pergande) (Thysanoptera: Thripidae) with special reference to interactions between thrips and tomato spotted wilt virus. Int. J. Insect Morphol. Embryol. 18: 289-310.

Van Rijn P.C.J., Mollema C. \& Steenhuis-Broers G.M. 1995: Comparative life-history studies of Frankliniella occidentalis and Thrips tabaci (Thysanoptera: Thripidae) on cucumber. Bull. Entomol. Res. 85: 285-297.

Yudin L.S., Tabashnik B.E., Cho J.J. \& Mitchell W.C. 1988: Colonization of weeds and lettuce by thrips (Thysanoptera: Thripidae). Envir. Entomol. 17: 522-526. 